\title{
Growth and gas exchanges of papaya tree seedlings grown on alternative substrates
}

\section{Crescimento e trocas gasosas de mudas de mamoeiro cultivadas em substratos alternativos}

\author{
Francico Vanies da Silva SÁ ${ }^{1}$; Marcos Eric Barbosa BRITO²; Luderlândio de Andrade SILVA \\ Lourival Ferreira CAVALCANTE ${ }^{4}$; Romulo Carantino Lucena MOREIRA ${ }^{5}$; Lizaiane Cardoso de \\ FIGUEIREDO ${ }^{6}$; Emanoela Pereira de PAIVA ${ }^{7}$
}

\begin{abstract}
${ }^{1}$ Autor para correspondência; Doutorando em Engenharia Agrícola; Universidade Federal de Campina Grande - UFCG; Centro Tecnologia e Recursos Naturais - CTRN; Campus Campina Grande, Rua Aprígio Veloso, 882 - Bairro Universitário, CEP 58.429-900, Campina Grande - PB, Brasil. E-mail: vanies_agronomia@hotmail.com

2 D. Sc. Professor da ; Universidade Federal de Campina Grande - UFCG; Unidade Acadêmica de Ciências Agrárias UAGRA; Campus Pombal. E-mail: marcoseric@ccta.ufcg.edu.br

${ }^{3}$ Mestrando em Hoticultura Tropical; Universidade Federal de Campina Grande - UFCG; Programa de Pós-Graduação em Hoticultura Tropical; - PPGHT, Campus Pombal. E-mail: luderlandioandrade@gmail.com

${ }^{4}$ D. Sc. Professor da Universidade Federal da Paraíba - UFPB; Centro de Ciências Agrárias - CCA; Campus II, Areia, PB. Email: lofeca@cca.ufpb.br

${ }^{5}$ Mestrando em Sistemas Agroindustriais; Universidade Federal de Campina Grande - UFCG; Programa de PósGraduação em Sistemas Agroindustriais; - PPGSA; Campus Pombal. E-mail: romulocarantino@gmail.com

${ }^{6}$ Mestranda em Hoticultura Tropical; Universidade Federal de Campina Grande - UFCG; Programa de Pós-Graduação em Hoticultura Tropical; - PPGHT; Campus Pombal. E-mail: lizaiane_ufcg@hotmail.com

${ }^{7}$ Doutoranda em Fitotecnia; Universidade Federal Rural do Semi-Árido - UFERSA; Departamento de Ciências Vegetais - DCV; Campus Mossoró. Email: emanuelappaiva@hotmail.com
\end{abstract}

Recebido em: 20-12-2014; Aceito em: 06-10-2015

\begin{abstract}
This study aimed at evaluating the morphophysiological development of papaya tree cultivars under different substrates, produced from mixtures of soil material with sources of organic matter. The experiment was conducted under greenhouse conditions. The experimental design was a randomized block, using a factorial $5 \times 2$ design with three replications, being five substrates with different sources of organic matter (S1 = 3 parts of soil and 1 of sand - without organic matter (control); $S 2=2$ parts of soil, 1 of sand and 1 of cattle manure; S3 = 2 parts of soil, 1 of sand and 1 of sheep manure; $S 4=2$ parts of soil, 1 of sand and 1 of chicken manure; $S 5=2$ parts of soil, $1 / 2$ of sand, $1 / 2$ of cattle manure, $1 / 2$ of sheep manure and $1 / 2$ of chicken manure) and two cultivars of papaya tree (Sunrise Solo and Tainung-01). The addition of organic matter, regardless of the source, favored the growth, the dry matter accumulation and the gas exchange of the papaya tree seedlings. The best growth is obtained when using the substrate ' 3 ', particularly when it relates to the dry mass of shoot and to the Dickson Quality Index.
\end{abstract}

Additional keywords: Carica papaya L.; organic fertilizer; propagation.

\section{Resumo}

Objetivou-se avaliar o desenvolvimento morfofisiológico de cultivares de mamoeiro sob diferentes substratos, produzidos a partir de misturas de material de solo com fontes de matéria orgânica. $O$ experimento foi realizado em ambiente protegido. O delineamento experimental foi 0 de blocos ao acaso, usando 0 esquema fatorial $5 \times 2$, com três repetições, tratando-se de cinco substratos com diferentes fontes de matéria orgânica ( $\mathrm{S} 1$ = 3 partes de solo e 1 de areia - sem matéria orgânica (controle); $\mathrm{S} 2=2$ partes de solo, 1 de areia e 1 de esterco bovino; S3= 2 partes de solo, 1 de areia e 1 de esterco ovino; $S 4=2$ partes de solo, 1 de areia e 1 de esterco de galinha; $S 5=2$ partes de solo, 1/2 de areia, $1 / 2$ de esterco bovino, $1 / 2$ de esterco ovino e $1 / 2$ de esterco de galinha) e duas cultivares de mamoeiro (Sunrise Solo e Tainung-01). A adição de matéria orgânica, independentemente da fonte, favoreceu o crescimento, o acúmulo de matéria seca e as trocas gasosas das mudas de mamoeiro. Obtém-se o melhor crescimento quando se usa o substrato ' 3 ', notadamente quando se relaciona à matéria seca da parte aérea e ao Índice de Qualidade de Dickson.

Palavras-chave adicionais: adubação orgânica; Carica papaya L.; propagação. 


\section{Introduction}

The papaya tree (Carica papaya L.) belongs to the family Caricaceae, it is a herbaceous plant, vigorous and highly productive, well suited to the Brazilian northeast. In the country, the culture contributes significantly in socioeconomic aspects, providing jobs and income, especially in the states of Bahia, Rio Grande do Norte and Ceará, main producers who, along with Espírito Santo, form the group of the country's largest exporters (IBGE, 2014).

It is also noteworthy that Brazil is ranked as the world's largest producer, with emphasis on the northeast region, which occupies the 1st place in the national ranking with $(60.4 \%)$ of the papaya offer. It is responsible for a production of $917,380 \mathrm{t}$, in a harvested area of 19,396 ha (IBGE, 2014), which allows to calculate a productivity of $47.3 \mathrm{t} \mathrm{ha}^{-1}$. However, part of the Brazilian northeast region is comprised of semiarid climate areas, about $70 \%$, limiting the development of the fruit trees in general, including the papaya tree, due to the climatic conditions and the low content of organic matter in the soils (Araújo et al., 2013).

According to Cavalcante et al. (2010), it is occurring an increase in areas planted with papaya tree in northeastern Brazil, being important the use of seedlings with high quality in the implementation of the orchard, especially from the most exploited cultivars in the region, as the Sunrise Solo and the hybrid Tainung-01, which are suitable to the international and domestic markets, respectively (Manica, 2006; Mesquita et al., 2012; Sá et al., 2013; Paiva et al., 2015).

The quality of the papaya tree seedlings is achieved through the use of technologies such as the proper selection of the irrigation system, containers, substrates and fertilizers, especially those of slowrelease, among others. Thus, the success of the agricultural production system depends, among other attributes, on the high-quality biological material, as well as on the achievement of seeds or seedlings to guarantee production and quality of fruits with economic viability. Constant studies are required, providing viable and accessible technologies to producers, especially in regions such as the northeast, where technology is a limiting factor to the expansion and maintenance of orchards in the region (Leitão et al., 2009; Sá et al., 2015; Paiva et al., 2015).

Among the factors required for the formation of high-quality seedlings, it is highlighted the use of substrates, ensuring support and pore space, water availability and sufficient nutrients to root growth. Although some studies report the efficiency of some agricultural inputs for the production of seedlings, one can find a plethora of agricultural inputs available on farms, which have potential for use and reuse in the production of substrates for production of seedlings; these require to be tested, isolated and in mixtures, in order to obtain the concentrations and types of inputs that best suit to each species (Melo et al., 2007; Leitão et al., 2009; Cavalcante et al., 2010; Costa et al., 2012; Mesquita et al., 2012; Araújo et al., 2013). It should be taken into account that the conditions of water and nutrient availability provided by the substrate can compromise the physiological activity and growth of the papaya tree seedlings (Melo et al., 2007; Mesquita et al., 2012; Paiva et al., 2015).

Therefore, this study aimed at evaluating the morphophysiological development of papaya tree cultivars in alternative substrates, produced from different sources and proportions of organic matter.

\section{Material and methods}

The experiment was conducted in a greenhouse, in the municipality of Pombal, PB, from January to March 2013. The experimental design was a complete randomized block, in a factorial scheme $(5 \times 2)$, with three replicates (three seedlings per replicate), being studied five substrates produced from mixtures of different organic matter sources (S1 = 3 parts of soil (Fulvic Neosol) and 1 of washed sand (control - with no organic matter), S2 $=2$ parts of soil, 1 of washed sand and 1 of cattle manure; S3 = 2 parts of soil, 1 of washed sand and 1 of sheep manure; S4 = 2 parts of soil, 1 of washed sand and 1 of chicken manure; S5 = 2 parts of soil, $1 / 2$ of sand, $1 / 2$ of cattle manure, $1 / 2$ of sheep manure and $1 / 2$ of chicken manure), their chemical characteristics being determined according to the methodology of Embrapa (1997) presented in Table 1, and two cultivars (C) of papaya tree $(\mathrm{C} 1=$ Sunrise Solo and C2 = Tainung-01).

The cultivation was performed in polyethylene tubes with a capacity of $0.3 \mathrm{dm}^{3}$, washed with $10 \%$ sodium hypochlorite. Seeds were sown at the rate of three seeds per tube, proceeding up the thinning when seedlings were with two definitive leaves, keeping the strongest plant per container. Throughout the experiment, the plants were maintained by the nutrients provided by the substrate.

At 60 days after sowing (DAS), it were

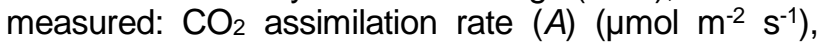
transpiration $(E)\left[\mathrm{mol}\left(\mathrm{H}_{2} \mathrm{O}\right) \mathrm{m}^{-2} \mathrm{~s}^{-1}\right]$, stomatal conductance (gs) [mol $\left(\mathrm{H}_{2} \mathrm{O}\right) \mathrm{m}^{-2} \mathrm{~s}^{-1}$ ] and internal $\mathrm{CO}_{2}$ concentration (Ci) $\left(\mu \mathrm{mol} \mathrm{mol}^{-1}\right)$ in the third leaf counted from the apex, using the portable equipment for measuring photosynthesis "LCPro+" from ADC BioScientific Ltd., operating with temperature control at $25^{\circ} \mathrm{C}$, irradiation of $1200 \mu \mathrm{mol}$ (photons) $\mathrm{m}^{-2} \mathrm{~s}^{-1}$ and air flow of $200 \mathrm{~mL} \mathrm{~min}^{-1}$, and $\mathrm{CO}_{2}$ from the environment at a height of $3 \mathrm{~m}$ from the ground surface. Having the data, it were quantified the water-use efficiency (WUE) $(A / E)\left[\left(\mu \mathrm{mol} \mathrm{m} \mathrm{m}^{-2} \mathrm{~s}^{-1}\right)\left[\mathrm{mol}\left(\mathrm{H}_{2} \mathrm{O}\right) \mathrm{m}^{-2} \mathrm{~s}^{-1}\right)^{-1}\right]$ and the instantaneous efficiency of carboxylation $\Phi \mathrm{C}(A / \mathrm{Ci})$ (Mendonça et al., 2010; Brito et al., 2012).

After the physiological evaluation, it were measured plant height $(\mathrm{PH})(\mathrm{cm})$ and stem diameter (SD) $(\mathrm{mm})$, with which were obtained the height/diameter ratio (HDR) and quantified the num- 
ber of leaves (NL) of the seedlings. Subsequently, the plants were collected, the roots being separated from shoots, and brought to the oven with air circulation at $65{ }^{\circ} \mathrm{C}$ until reaching constant mass to determine the dry mass of root (DMR) (g) and shoot (DMS) (g), the total dry mass (TDM) (g), by the sum of both, and the root/shoot ratio (RSR), by the quotient between the values of dry mass of root and shoot.

Table 1 - Chemical properties of the substrates (Sub) used for the production of papaya seedlings.

\begin{tabular}{|c|c|c|c|c|c|c|c|c|c|c|c|c|c|}
\hline Sub & pH & $\begin{array}{c}\mathrm{P} \\
\left(\mathrm{mg} \mathrm{kg}^{-1}\right)\end{array}$ & K & $\mathrm{Na}$ & $\mathrm{Ca}$ & $\begin{array}{l}\mathrm{Mg} \\
-(\mathrm{cm}\end{array}$ & $\begin{array}{c}\mathrm{H}+\mathrm{Al} \\
\left.\mathrm{l}_{\mathrm{c}} \mathrm{dm}^{-3}\right)\end{array}$ & SB & CTC & $\begin{array}{c}\text { M.O. } \\
\left(\mathrm{g} \mathrm{kg}^{-1}\right)\end{array}$ & $\begin{array}{c}\mathrm{V} \\
(\%)\end{array}$ & $\begin{array}{l}\text { PST } \\
(\%)\end{array}$ & $\begin{array}{c}\mathrm{CE} \\
\left.(\mathrm{dSm})^{-1}\right)\end{array}$ \\
\hline 1 & 8.26 & 8.0 & 0.39 & 0.43 & 4.9 & 6.7 & 0.0 & 11.99 & 11.99 & 15 & 100 & 3.45 & 0.15 \\
\hline 2 & 8.09 & 10.0 & 0.45 & 0.07 & 3.9 & 4.6 & 0.0 & 8.95 & 8.95 & 39 & 100 & 0.79 & 0.75 \\
\hline 3 & 7.64 & 11.0 & 0.66 & 0.07 & 6.5 & 6.8 & 0.0 & 13.96 & 13.96 & 39 & 100 & 0.51 & 1.86 \\
\hline 4 & 7.40 & 9.0 & 0.25 & 0.07 & 3.8 & 8.1 & 0.0 & 12.15 & 12.15 & 36 & 100 & 0.58 & 0.69 \\
\hline 5 & 7.03 & 11.0 & 0.33 & 0.07 & 5.2 & 6.1 & 0.0 & 11.63 & 11.63 & 68 & 100 & 0.61 & 0.73 \\
\hline
\end{tabular}

$\mathrm{S} 1$ = 3 parts of soil (Neossolo Fúlvico) and 1 of washed sand (testemunha- without organic matter); $\mathrm{S} 2=2$ parts of soil, 1 of washed sand and 1 of cattle manure; S3 = 2 parts of soil, 1 of washed sand and 1 sheep manure; S4 = 2 parts of soil, 1 of washed sand and 1 of chicken manure; $S 5=2$ parts of soil, $1 / 2$ of sand, $1 / 2$ of cattle manure, $1 / 2$ of sheep manure and $1 / 2$ of chicken manure; $P, K, N a$ : extractor Mehlich1; Al, Ca, Mg: extracting KCl $1.0 \mathrm{~mol} \mathrm{~L}^{-1} ; \mathrm{SB}=\mathrm{Ca}^{+2}+\mathrm{Mg}^{+2}+\mathrm{H}^{+}+\mathrm{Na}^{+} ; \mathrm{H}^{+}+\mathrm{Al}^{+3}$ : extractor Calcium Acetate $0.5 \mathrm{~mol} \mathrm{~L} \mathrm{~L}^{-1}, \mathrm{pH}^{2} .0$; $\mathrm{CTC}=\mathrm{SB}+\mathrm{H}^{+}+\mathrm{Al}^{+3}$; M.O.: Digestion Wet Walkley-Black; PST = Percentage exchangeable sodium $\left.\left(\mathrm{Na}^{+} / \mathrm{CTC}\right){ }^{*} 100\right) ; \mathrm{CE}=\mathrm{Electrical}$ conductivity of $1: 2.5$.

It was also estimated the quality of the papaya tree seedlings using the Dickson quality index (DQI), which is a balanced formula, wherein are included the ratios of the growth variables (Dickson et al., 1960), described in Equation. 1 and expressed in $\mathrm{g} \mathrm{cm}^{-1}$ :

$$
\mathrm{DQI}=\frac{\mathrm{TDM}}{\frac{\mathrm{PH}}{\mathrm{SD}}+\frac{\mathrm{DMS}}{\mathrm{DMR}}}
$$

Wherein: DQI is the Dickson quality index $\left(\mathrm{g} \mathrm{cm}^{-1}\right)$; TDM is the total dry mass (g); DMS is the dry mass of shoot (g); DMR is the dry mass of root $(\mathrm{g}), \mathrm{PH}$ is plant height $(\mathrm{cm})$; and SD is the stem diameter $(\mathrm{mm})$.

The variables were subjected to analysis of variance ( $\mathrm{F}$ test) and Tukey test to $5 \%$ probability, using the Sisvar software (Ferreira, 2011).

\section{Results and discussions}

By the analysis of variance, the interaction substrate $x$ cultivar had significant effects only on the issue of leaves by the seedlings (Table 2). The growth in height and the stem diameter, as well as the production of dry mass of root, the total dry mass and the Dickson quality index responded to the isolated effects of both the sources of variation. The dry mass of shoot and the root/shoot ratio responded to the isolated effect of the substrates. As for the height/diameter ratio, it suffered significant interference of the isolated effect of cultivars.

Table 2 - Summary analysis of variance related to variables plant height (HP), stem diameter (SD), number of leaves (NL), dry matter of shoot (SDM) and roots (RDM), total dry matter (TDM), Dickson quality index (DQI), height / diameter (HDR) and root / shoot (RSR) at 60 days after sowing, on the varieties of papaya grown on substrates with different sources of organic matter.

\begin{tabular}{lcccccccccc}
\hline \multirow{2}{*}{ SV } & \multirow{2}{*}{ DF } & \multicolumn{10}{c}{ Mean square } \\
\cline { 2 - 11 } & & HP & SD & NL & SDM & RDM & TDM & DQI & HDR & RSR \\
\hline S & 4 & $31.18^{* *}$ & $12.73^{* *}$ & $2.34^{* *}$ & $0.66^{* *}$ & $0.103^{* *}$ & $1.26^{* *}$ & $0.074^{* *}$ & $0.03^{\text {ns }}$ & $0.125^{* *}$ \\
C & 1 & $125.74^{* *}$ & $7.77^{* *}$ & $0.0001^{\text {ns }}$ & $0.11^{\text {ns }}$ & $0.158^{* *}$ & $0.53^{* *}$ & $0.037^{* *}$ & $1.14^{* *}$ & $0.009^{\text {ns }}$ \\
S x C & 4 & $1.88^{\text {ns }}$ & $0.20^{\text {ns }}$ & $1.11^{*}$ & $0.06^{\text {ns }}$ & $0.001^{\text {ns }}$ & $0.08^{\text {ns }}$ & $0.001^{\text {ns }}$ & $0.02^{\text {ns }}$ & $0.038^{\text {ns }}$ \\
Blocks & 2 & 1.91 & 0.41 & 0.20 & $0.01^{\text {ns }}$ & $0.003^{\text {ns }}$ & $0.02^{\text {ns }}$ & $0.002^{\text {ns }}$ & $0.03^{\text {ns }}$ & $0.025^{\text {ns }}$ \\
Error & 18 & 0.73 & 0.52 & 0.37 & 0.06 & 0.003 & 0.08 & 0.003 & 0.04 & 0.031 \\
\hline CV $(\%)$ & & 8.34 & 11.88 & 7.83 & 37.46 & 15.86 & 26.99 & 19.33 & 12.46 & 25.65 \\
\hline
\end{tabular}

SV - sources of variation; S - substrates; C - cutivars; DF - degrees of freedom; CV = coefficient of variation ${ }^{\star \star}-1 \%$ probability $(F$ test); * $-5 \%$ probability ( $F$ test); ns - not significant $(F$ test).

The plants grew more in height on the substrates formed from organic materials in relation to the control treatment (Table 3) and with superiority of the seedlings relating to the cultivar Tainung-01. The growth in height is a very important aspect to represent the good performance of the seedlings. According to Manica (2006), the perfect height for the papaya seedlings to be brought to the field is close to $15 \mathrm{~cm}$, which was observed in the cultivar Tainung-01 developed in the substrate ' 3 ' (2 soil: 1 sand: 1 sheep manure), which was added with sheep manure, yielding therefore greater precocity in relation to other treatments (Table 3).

The result in plant height featured in the substrate ' 3 ' ( 2 soil: 1 sand: 1 sheep manure), of the cultivar Tainung-01, exceeds the $13.72 \mathrm{~cm}$ in Formosa 
papaya seedlings obtained by Teixeira et al. (2009), under application of lithothamnium and organic-mineral substrates, which can be attributed to the conditions of nutrient supply of this substrate, for example the potassium (Table 1).

As for the stem diameter, the behavior was similar to that observed for seedling height, with the highest values in plants grown in substrates prepared with organic materials, when compared to those of the control treatment (Table 3). Considering that these results may be related to the higher concentration of phosphorus and potassium observed on the substrates with the addition of organic matter (Table 1). For Araújo et al. (2013), the substrates should possess physical properties, such as aeration and drainage, and chemical properties, providing nutrients in adequate quantities for plant growth.

Table 3 - Comparison test of mean (Tukey), related to variables plant height, stem diameter and number of leaves of different varieties of papaya grown on substrates with different sources of organic matter.

\begin{tabular}{crrrccc}
\hline \multirow{2}{*}{ Substrates (S) } & \multicolumn{2}{c}{ Height $(\mathrm{cm})$} & \multicolumn{2}{c}{ Stem diameter $(\mathrm{mm})$} & \multicolumn{2}{c}{ Number of leaves } \\
\cline { 2 - 7 } & \multicolumn{2}{c}{ Cultivars } & \multicolumn{2}{c}{ Cultivars } & \multicolumn{2}{c}{ Cultivars } \\
\cline { 2 - 7 } & Sunrise Solo & Tainung-01 & Sunrise Solo & Tainung-01 & Sunrise Solo & Tainung-01 \\
\hline 1 & $5.30 \mathrm{Bb}$ & $7.46 \mathrm{Ba}$ & $3.26 \mathrm{Ba}$ & $4.03 \mathrm{Ba}$ & $6.66 \mathrm{Bb}$ & $7.76 \mathrm{ABa}$ \\
2 & $8.28 \mathrm{Ab}$ & $12.95 \mathrm{Aa}$ & $5.28 \mathrm{Aa}$ & $6.92 \mathrm{Aa}$ & $8.11 \mathrm{ABa}$ & $7.21 \mathrm{Ba}$ \\
3 & $10.13 \mathrm{Ab}$ & $14.67 \mathrm{Aa}$ & $6.97 \mathrm{Aa}$ & $7.73 \mathrm{Aa}$ & $8.95 \mathrm{Aa}$ & $8.76 \mathrm{Aa}$ \\
4 & $8.08 \mathrm{Ab}$ & $13.05 \mathrm{Aa}$ & $6.06 \mathrm{Aa}$ & $6.90 \mathrm{Aa}$ & $7.33 \mathrm{Ba}$ & $8.01 \mathrm{ABa}$ \\
5 & $9.18 \mathrm{Ab}$ & $13.31 \mathrm{Aa}$ & $6.42 \mathrm{Aa}$ & $7.51 \mathrm{Aa}$ & $7.88 \mathrm{ABa}$ & $7.21 \mathrm{Ba}$ \\
\hline
\end{tabular}

$\mathrm{S} 1=3$ parts of soil (Neossolo Fúlvico) and 1 of washed sand (testemunha- without organic matter); $\mathrm{S} 2=2$ parts of soil, 1 of washed sand and 1 of cattle manure; S3 = 2 parts of soil, 1 of washed sand and 1 sheep manure; S $4=2$ parts of soil, 1 of washed sand and 1 of chicken manure; $S 5=2$ parts of soil, $1 / 2$ of sand, $1 / 2$ of cattle manure, $1 / 2$ of sheep manure and $1 / 2$ of chicken manure; Capital letters describe the effects of substrate within each cultivar and lowercase letters, the difference between cultivars in the given substrate.

The substrates stimulated the issue of leaves of the papaya tree cultivars differently in each cultivar, and the substrate ' 3 ' (2 soil: 1 sand: 1 sheep manure) provided greater number of leaves in the papaya tree cultivar Tainung-01, compared to the substrates ' 2 ' ( 2 soil: 1 sand: 1 cattle manure) and ' 5 ' ( 2 soil: $1 / 2$ sand: $1 / 2$ cattle manure: $1 / 2$ sheep manure: $1 / 2$ chicken manure), while in the cultivar Sunrise Solo, the substrates '2' ( 2 soil: 1 sand: 1 cattle manure), '3' (2 soil: 1 sand: 1 sheep manure) and '5' (2 soil: 1/2 sand: $1 / 2$ cattle manure: $1 / 2$ sheep manure: $1 / 2$ chicken manure) are highlighted (Table 3 ).

It is noteworthy that the leaves are the organs responsible for about $90 \%$ of the accumulated dry matter in plants, resulting from the photosynthetic activity, and that it is the structure responsible for producing most of the essential carbohydrates to the growth and development of plants (Taiz \& Zeiger, 2013), this way, substrates that speed up the issue of leaves form seedlings of better quaity and thereby provide greater survival in the field.

The accumulation of dry mass of shoot of the papaya tree seedlings was influenced by the source and proportion of organic matter in the substrate; according to the results, the substrate ' 3 ' (2 soil: :1 sand: 1 sheep manure) promoted the highest dry matter accumulation with $1.15 \mathrm{~g}$, surpassing by 4.6 times the value determined in the seedlings of the control treatment (Figure 1).

The distribution of dry matter among the different organs of a plant is the end result of an ordered set of processes regarding the metabolism and transport of photoassimilates, which depend on the nutrition and water conditions of the plants (Taiz \&
Zeiger, 2013). Hence, the dry matter accumulation is directly related to the quality of the substrate and its ability to provide water and nutrients to plants. By comparison, the values obtained by the substrate ' 3 ' (2 soil: 1 sand: 1 sheep manure) were similar to 1.16 and $0.91 \mathrm{~g} \mathrm{plant}^{-1}$ DMS recorded by Melo et al. (2007) and Araújo et al. (2013), respectively, studying different organic substrates and phosphorus levels in the production of papaya tree seedlings.

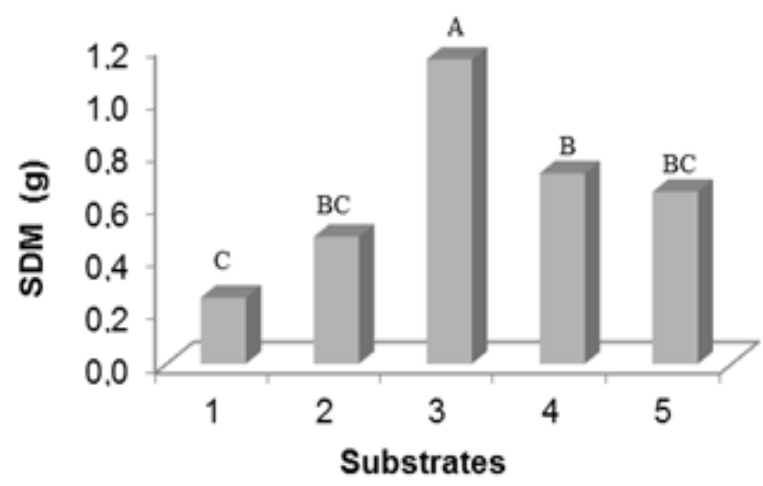

Figure 1 - Shoots dry matter of (SDM) of papaya seedlings in relation to substrates with different sources of organic matter.

Equal capital letters on the columns means that the averages do not differ by Tukey test $(p<0.05)$.

Note: $\mathrm{S} 1=3$ parts soil (Fulvic Neosol) and 1 of washed sand (control- without organic matter); S2 $=2$ pieces of land, 1 of washed sand and 1 of cattle manure; $S 3=2$ pieces of land, 1 of washed sand and 1 sheep manure; $S 4=2$ pieces of land, 1 of washed sand and 1 chicken manure; S5 $=2$ parts soil, sand $1 / 2,1 / 2$ of manure, sheep manure $1 / 2$ and $1 / 2$ chicken manure. 
There was a significant difference between the varieties of papaya tree with regard to the accumulation of dry mass of root (DMR), so that the highest averages were found in the cultivar Tainung-01 . As for the substrate, it is observed that the substrate ' 3 ' (2 soil: 1 sand: 1 sheep manure) provided the largest accumulation of dry mass of root for both cultivars (Table 4). The results of the seedlings of the substrate ' 3 ' ( 2 soil: 1 sand: 1 sheep manure) were 0.51 and $0.64 \mathrm{~g} \mathrm{plant}^{-1}$ for the cultivars Sunrise Solo and Tainung-01, respectively, exceeding those presented by Teixeira et al. (2009) in Formosa papaya seedlings grown in commercial substrate Plantmax $\AA^{\circledR}$ sand + soil at the ratio of $1: 1: 3$.

The substrates ' 1 ' ( 2 soil: 1 sand), ' 2 ' ( 2 soil: 1 sand: 1 cattle manure) and '4' (2 soil: 1 sand: 1 chicken manure) were the least efficient in producing dry matter of seedlings of the cultivar Sunrise Solo, with losses of respectively $68.6,43.1$ and $43.1 \%$ in relation to the accumulation of dry mass of roots obtained from the plants grown in substrate ' 3 ' ( 2 soil: $: 1$ sand: 1 sheep manure) (Table 4). From the results, the proportions of bovine and chicken manure used were insufficient to promote suitable root growth to the cultivar Sunrise Solo. For Mesquita et al. (2012), the substrate containing $66 \%$ of bovine manure in one liter containers promote greater accumulation of dry mass of roots to the cultivar Sunrise Solo, yet for Melo et al. (2007), the beneficial effects of chicken manure for papaya tree are obtained when there is a percentage between 45 and $60 \%$ in the substrate. Compared to the substrate ' 3 ', which contains only $25 \%$ of organic matter derived from sheep manure, the results are similar to those obtained by the aforementioned authors.

With regard to the cultivar Tainung-01, all substrates resulted in accumulations of dry mass of roots at least $45 \%$ higher than the control treatment (Table 4). This superiority indicates the cultivar requirement for substrates based on organic matter (Table 1). Thus, the studied substrates can be used as an alternative to the formation of seedlings of the papaya tree cultivar Tainung-01, considering that plants with higher contribution of the root system, in most cases, have greater growth in the field after transplanting (Melo et al., 2007).

Table 4 - Comparison test of mean (Tukey) on variables root dry matter and total dry matter between the papaya cultivars in each substrate and between substrates in each variety of papaya.

\begin{tabular}{|c|c|c|c|c|}
\hline \multirow{3}{*}{ Substrates (S) } & \multicolumn{2}{|c|}{ root dry matter $(\mathrm{g})$} & \multicolumn{2}{|c|}{ total dry matter $(\mathrm{g})$} \\
\hline & \multicolumn{2}{|c|}{ Cultivars } & \multicolumn{2}{|c|}{ Cultivars } \\
\hline & Sunrise Solo & Tainung-01 & Sunrise Solo & Tainung-01 \\
\hline 1 & $0.16 \mathrm{Ca}$ & $0.26 \mathrm{Ca}$ & $0.35 \mathrm{Ba}$ & $0.57 \mathrm{Ba}$ \\
\hline 2 & $0.29 \mathrm{BCb}$ & $0.46 \mathrm{Ba}$ & $0.60 \mathrm{Bb}$ & $1.13 \mathrm{ABa}$ \\
\hline 3 & $0.51 \mathrm{Ab}$ & $0.64 \mathrm{Aa}$ & $1.74 \mathrm{Aa}$ & $1.71 \mathrm{Aa}$ \\
\hline 4 & $0.29 \mathrm{BCb}$ & $0.48 \mathrm{Ba}$ & $0.87 \mathrm{Ba}$ & $1.35 \mathrm{Aa}$ \\
\hline 5 & $0.36 \mathrm{ABb}$ & $0.49 \mathrm{ABa}$ & $1.01 \mathrm{Ba}$ & $1.16 \mathrm{ABa}$ \\
\hline
\end{tabular}

$\mathrm{S} 1$ = 3 parts of soil (Neossolo Fúlvico) and 1 of washed sand (testemunha- without organic matter); $\mathrm{S} 2=2$ parts of soil, 1 of washed sand and 1 of cattle manure; S3 = 2 parts of soil, 1 of washed sand and 1 sheep manure; $S 4=2$ parts of soil, 1 of washed sand and 1 of chicken manure; $S 5=2$ parts of soil, $1 / 2$ of sand, $1 / 2$ of cattle manure, $1 / 2$ of sheep manure and $1 / 2$ of chicken manure; Capital letters describe the effects of substrate within each cultivar and lowercase letters, the difference between cultivars in the given substrate.

The substrate ' 3 ' $(2$ soil: 1 sand: 1 sheep manure) proved to be more promising to the accumulation of total dry mass of papaya tree seedlings. It is also observed that when the seedlings were grown on the substrate ' 2 ' ( 2 soil: 1 sand: 1 cattle manure), the accumulation of total dry mass of the cultivar Tainung-01 exceeded by 1.88 times the accumulation of total dry mass of the cultivar Sunrise Solo (Table 4). One can associate this behavior with the increased sensitivity of the cultivar Tainung-01 to the alkalinity of the substrate, in relation to the cultivar Sunrise Solo, considering the brief reduction in the $\mathrm{pH}$, from 8.26 on the substrate ' 1 ' (where the cultivars did not statistically differ) to 8.06 on the substrate '2', promoting significant increase in the dry matter accumulation of this cultivar. The greater sensitivity to alkalinity of the cultivar Tainung-01 in relation to the
Sunrise Solo was also identified by Sá et al. (2013), evaluating the production of seedlings of papaya tree cultivars under salt stress, where the cultivar Tainung-01 had lower accumulation of phytomass in relation to the cultivar Sunrise Solo in the most alkaline medium (Table 1).

The best seedlings were obtained, in the substrate ' 3 ' (2 soil: 1 sand: 1 sheep manure), according to the greatest values of Dickson quality index, in the range of 0.47 and $0.44 \mathrm{~g} \mathrm{~cm}^{-1}$ to cultivars Tainung-01 and Sunrise Solo, respectively; these results indicate the potential of this substrate as an alternative for the production of seedlings of papaya tree in the semiarid region (Table 5). And the highest Dickson quality indexes, relating to the cultivar Tainung-01, indicate its greater potential for development (Table 5). 
Table 5 - Comparison test of mean (Tukey) on the variable Dickson quality index among papaya cultivars in each substrate and between substrates in each variety of papaya.

\begin{tabular}{ccc}
\hline \multirow{2}{*}{$\begin{array}{c}\text { Substrates } \\
\text { (S) }\end{array}$} & \multicolumn{2}{c}{ Dickson quality index (DQI) $\left(\mathrm{g} \mathrm{cm}^{-1}\right)$} \\
\cline { 2 - 3 } & \multicolumn{2}{c}{ Cultivars } \\
\cline { 2 - 3 } 1 & Sunrise Solo & Tainung-01 \\
2 & $0.12 \mathrm{Ca}$ & $0.17 \mathrm{Ba}$ \\
3 & $0.23 \mathrm{BCb}$ & $0.33 \mathrm{Aa}$ \\
4 & $0.44 \mathrm{Aa}$ & $0.47 \mathrm{Aa}$ \\
5 & $0.26 \mathrm{BCa}$ & $0.36 \mathrm{Aa}$ \\
& $0.31 \mathrm{ABa}$ & $0.37 \mathrm{Aa}$
\end{tabular}

S1 = 3 parts of soil (Neossolo Fúlvico) and 1 of washed sand (testemunha- without organic matter); S2 $=2$ parts of soil, 1 of washed sand and 1 of cattle manure; S3 = 2 parts of soil, 1 of washed sand and 1 sheep manure; $S 4=2$ parts of soil, 1 of washed sand and 1 of chicken manure; S5 = 2 parts of soil, $1 / 2$ of sand, $1 / 2$ of cattle manure, $1 / 2$ of sheep manure and $1 / 2$ of chicken manure; Capital letters describe the effects of substrate within each cultivar and lowercase letters, the difference between cultivars in the given substrate.

A

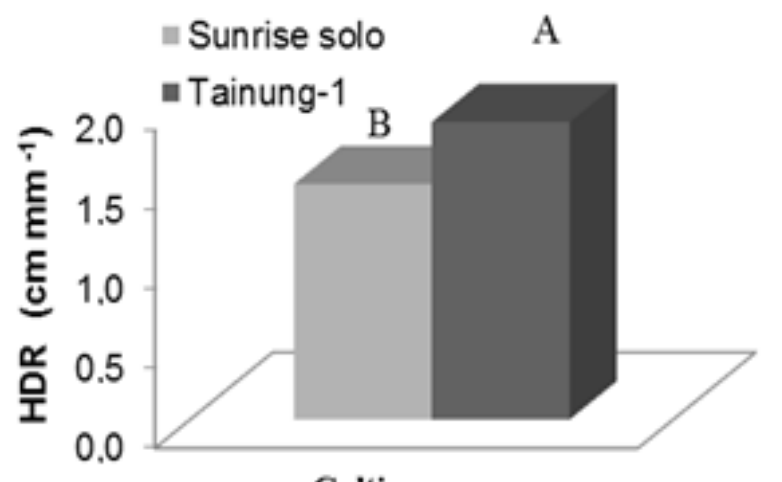

Cultivars
The different substrates did not influence the height/stem diameter ratio (HDR) of the papaya tree cultivars. On the other hand, these cultivars showed distinct growth potentials, since in the cultivar Tainung-01 there was a greater height/stem diameter ratio compared to the Sunrise Solo, with values of 1.87 and $1.48 \mathrm{~cm} \mathrm{~mm}^{-1}$, respectively, corresponding to a difference of $20.8 \%$ (Figure $2 \mathrm{~A}$ ).

When considering that the height/stem diameter ratio refers to the balance of plant growth, it can be said that values close to 1.0 are more interesting, since they refer to the balance between the variables and denote a smaller influence of abiotic stress, for example nutritional disorders and the occurrence of etiolation of seedlings, thereby providing greater resistance to field conditions. Also noteworthy is that the HDR is not a good variable to take as a reference for quality in papaya tree seedlings, since in the seedlings of the cultivar Tainung01, although it has been noticed greater HDR values, it was also observed greater vigor, with no limitations regarding the seedling quality, as noted in the Dickson quality index. The inefficiency of the HDR as a reference of quality in seedlings was observed by Costa et al. (2012) in tamarind tree.

B

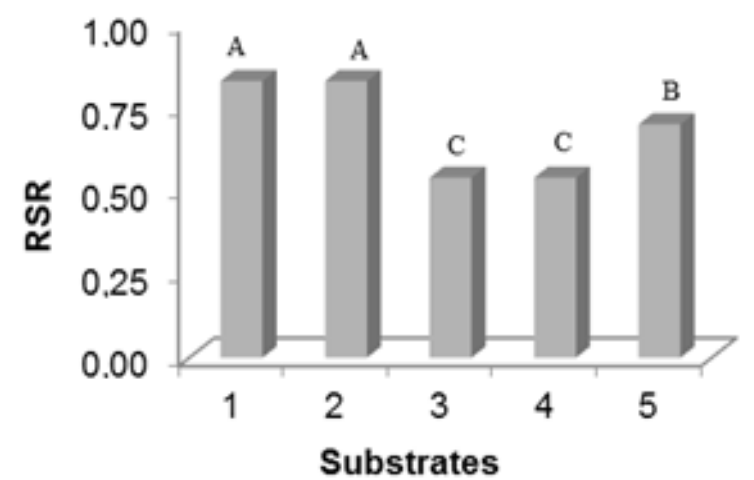

Figure 2 - (A) height/diameter ratio (HDR) and (B) root / shoot ratio (RSR) of papaya seedlings in relation to cultivars and substrates with different sources of organic matter, respectively.

Equal capital letters on the columns means that the averages do not differ by Tukey test $(p<0.05)$.

Note: $\mathrm{S} 1$ = 3 parts of soil (Neossolo Fúlvico) and 1 of washed sand (testemunha- without organic matter); S2 = 2 parts of soil, 1 of washed sand and 1 of cattle manure; S3 = 2 parts of soil, 1 of washed sand and 1 sheep manure; S4 = 2 parts of soil, 1 of washed sand and 1 of chicken manure; S5 = 2 parts of soil, $1 / 2$ of sand, $1 / 2$ of cattle manure, $1 / 2$ of sheep manure and $1 / 2$ of chicken manure.

As can be seen in Figure 2B, the highest values of the root/shoot ratio were obtained in the papaya tree seedlings grown in the substrates ' 1 ' (2 soil: 1 sand) and '2' ( 2 soil: 1 sand: 1 cattle manure) with values of $0.83 \mathrm{~g} \mathrm{~g}^{-1}$ (Figure 2B). The increase in the root/shoot ratio indicates growth of the root system so as to provide greater soil exploration for absorbing water and nutrients (Sá et al., 2013). From the results, the increased root/shoot ratio in the seedlings of papaya tree, grown in the substrates ' 1 ' and ' 2 ', is a reflection of high levels of $\mathrm{pH}$ of the substrate, possibly caused by low availability of cationic micronutrients.
According to Table 6, the interaction substrate $x$ cultivars interfered with significant effects only in the internal $\mathrm{CO}_{2}$ concentration and in the instantaneous efficiency of carboxylation. The diifferent substrates significantly affected the transpiration, stomatal conductance, net assimilation rate, and water use efficiency by the papaya tree seedlings. Despite the significant influence, the results obtained in the research express rates of transpiration, stomatal conductance, $\mathrm{CO}_{2}$ assimilation rate and internal $\mathrm{CO}_{2}$ concentration consistent with the data reported in the literature for papaya plants (Reis \& Campostrine, 2011). 
The biggest internal $\mathrm{CO}_{2}$ concentrations $(\mathrm{Ci})$ were observed in the seedlings grown in substrate ' 1 ' ( 2 soil: 1 sand), regardless of the cultivar (Table 7). A fact that may be related to the alkalinity of the substrate, in view of its high $\mathrm{pH}$, promoting salt stress in the plant, and thereby affecting the activity of the enzyme ribulose 1,5-bisphosphate carboxylaseoxygenase (Rubisco), reducing $\mathrm{CO}_{2}$ assimilation and consequently increasing the concentration of $\mathrm{CO}_{2}$ in the substomatal chamber (Machado et al., 2005; Silva et al., 2014).

Table 6 - Summary analysis of variance on the variables intercellular $\mathrm{CO}_{2}$ concentration $(\mathrm{Ci})$, transpiration $(\mathrm{E})$, stomatal conductance $(g s), \mathrm{CO}_{2}$ assimilation rate $(\mathrm{A})$, water use efficiency (WUE) and instantaneous efficiency of carboxylation $(\Phi C)$ on varieties of papaya grown on substrates with different sources of organic matter.

\begin{tabular}{lccccccc}
\hline \multirow{2}{*}{ SV } & \multirow{2}{*}{ DF } & \multicolumn{7}{c}{ Mean square } \\
\cline { 3 - 8 } & & $\mathrm{Ci}$ & $\mathrm{E}$ & \multicolumn{1}{c}{$g s$} & $\mathrm{~A}$ & WUE & $\Phi \mathrm{C}$ \\
\hline S & 4 & $2056.25^{* *}$ & $0.488^{* *}$ & $0.0021^{*}$ & $9.58^{* *}$ & $2.06^{* *}$ & $0.000329^{* *}$ \\
$\mathrm{C}$ & 1 & $448.53^{\text {ns }}$ & $0.006^{\text {ns }}$ & $0.0003^{\text {ns }}$ & $0.02^{\text {ns }}$ & $0.05^{\text {ns }}$ & $0.000002^{\text {ns }}$ \\
S x C & 4 & $1359.61^{* *}$ & $0.150^{\text {ns }}$ & $0.0006^{\text {ns }}$ & $0.71^{\text {ns }}$ & $0.33^{\text {ns }}$ & $0.000132^{* *}$ \\
Blocks & 2 & $999.23^{* *}$ & $0.005^{\text {ns }}$ & $0.0004^{\text {ns }}$ & $0.66^{\text {ns }}$ & $0.29^{\text {ns }}$ & $0.000027^{\text {ns }}$ \\
Error & 18 & 185.67 & 0.062 & 0.0007 & 1.38 & 0.23 & 0.000035 \\
\hline CV $(\%)$ & & 5.40 & 13.60 & 26.54 & 18.70 & 14.55 & 23.29 \\
\hline
\end{tabular}

SV - sources of variation; $S$ - substrates; C - cutivars; DF - degrees of freedom; CV $=$ coefficient of variation ${ }^{* *}-1 \%$ probability $(F$ test); * $-5 \%$ probability $(F$ test); ns - not significant $(F$ test).

When evaluating the performance of cultivars in different substrates, it is observed in the seedlings of the cultivar Tainung-01, produced in the substrate ' 5 ' ( 2 soil: $1 / 2$ sand: $1 / 2$ cattle manure: $1 / 2$ sheep manure: $1 / 2$ chicken manure), higher internal concentrations of $\mathrm{CO}_{2}$ in relation to those of the cultivar Sunrise Solo, notwithstanding, the observed values are within the range described by Taiz \& Zeiger (2013) to C3 plants (between 240 and $280 \mu \mathrm{mol} \mathrm{mol}^{-1}$ ), indicating efficient $\mathrm{CO}_{2}$ influx of seedlings, regardless of the substrate studied.

Table 7 - Comparison test of mean (Tukey) on the variable intercellular $\mathrm{CO}_{2}$ concentration $(\mathrm{Ci})$ between the papaya cultivars in each substrate and between substrates in each varieties of papaya.

\begin{tabular}{ccc}
\hline \multirow{2}{*}{$\begin{array}{c}\text { Substrates } \\
(\mathrm{S})\end{array}$} & \multicolumn{2}{c}{$\begin{array}{c}\text { Intercellular } \mathrm{CO}_{2} \text { concentration } \\
(\mathrm{Ci})\left(\mu \mathrm{mol} \mathrm{mol}^{-1}\right)\end{array}$} \\
\cline { 2 - 3 } & \multicolumn{2}{c}{ Cultivars } \\
\cline { 2 - 3 } & Sunrise Solo & Tainung-01 \\
\hline 1 & $277.66 \mathrm{Aa}$ & $282.33 \mathrm{Aa}$ \\
2 & $254.33 \mathrm{ABa}$ & $255.33 \mathrm{Ba}$ \\
3 & $250.66 \mathrm{ABa}$ & $215.00 \mathrm{Ba}$ \\
4 & $226.66 \mathrm{Ba}$ & $249.33 \mathrm{Ba}$ \\
5 & $233.00 \mathrm{Bb}$ & $279.00 \mathrm{Ba}$ \\
\hline
\end{tabular}

S1 = 3 parts of soil (Neossolo Fúlvico) and 1 of washed sand (testemunha- without organic matter); S2 $=2$ parts of soil, 1 of washed sand and 1 of cattle manure; S3 $=2$ parts of soil, 1 of washed sand and 1 sheep manure; S4 = 2 parts of soil, 1 of washed sand and 1 of chicken manure; $S 5=2$ parts of soil, $1 / 2$ of sand, $1 / 2$ of cattle manure, $1 / 2$ of sheep manure and $1 / 2$ of chicken manure; Capital letters describe the effects of substrate within each cultivar and lowercase letters, the difference between cultivars in the given substrate.

Among the substrates studied, the '4' (2 soil: 1 sand: 1 chicken manure) stands out, for giving the papaya tree seedlings the greatest transpiration [2.2 mol $\left(\mathrm{H}_{2} \mathrm{O}\right) \mathrm{m}^{-2} \mathrm{~s}^{-1}$, yet the lowest values were observed in the seedlings grown in substrate ' 3 ' ( 2 soil: 1 sand: 1 sheep manure) $\left[1.49 \mathrm{~mol}\left(\mathrm{H}_{2} \mathrm{O}\right) \mathrm{m}^{-2} \mathrm{~s}^{-1}\right.$, being $32.2 \%$ lower than that obtained in the substrate ' 4 ' (Figure $3 \mathrm{~A}$ ).

Possibly the greater transpirations obtained by seedlings grown in the substrates ' 1 ' ( 2 soil: 1 sand), ' 2 ' ( 2 soil: 1 sand: 1 cattle manure), ' 4 ' and ' 5 ' ( 2 soil: $1 / 2$ sand: $1 / 2$ cattle manure: $1 / 2$ sheep manure: $1 / 2$ chicken manure) over the substrate ' 3 ' (Figure $3 A$ ) are related to the need to regulate the temperature of plants, and to enhance the absorption of mineral nutrients, promoting the development of plants (Taiz \& Zeiger, 2013).

In the seedlings produced with the substrates ' 2 ' ( 2 soil: 1 sand: 1 cattle manure), ' 4 ' (2 soil: 1 sand: 1 chicken manure) and ' 5 ' ( 2 soil: $1 / 2$ sand: $1 / 2$ cattle manure: $1 / 2$ sheep manure: $1 / 2$ chicken manure), it was observed the highest value of stomatal conductance, $0.11\left(\mathrm{~mol} \mathrm{H}_{2} \mathrm{O} \mathrm{m} \mathrm{m}^{-2} \mathrm{~s}^{-1}\right)$, exceeding by $36 \%$ the value of $0.7\left(\mathrm{~mol} \mathrm{H}_{2} \mathrm{O} \mathrm{m}^{-2} \mathrm{~s}^{-1}\right)$, obtained in plants grown in the substrate ' 1 ' (control without organic matter) and ' 3 ' (2 soil: 1 sand: 1 sheep manure) (Figure 3B). This superiority indicates the importance of using organic sources in the production of seedlings of papaya tree, as the stomatal conductance is one of the limiting factors for proper regulation of the photosynthesis (Reis \& Campostrine, 2011). Nonetheless, the results obtained in substrate ' 3 ' (2 soil: 1 sand: 1 manure sheep) can be related to the need to reduce the transpiration activity in view of the water loss, considering that the seedlings of this treatment had the highest growth and number of leaves, and this behavior did not compromise the water use efficiency (Figure 3D). 
A

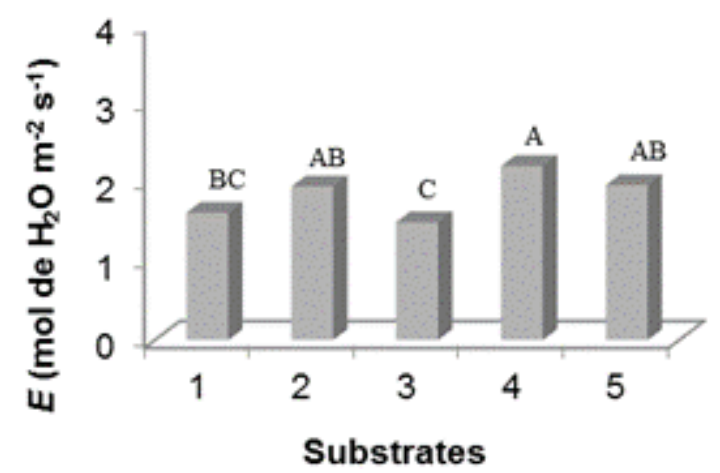

C

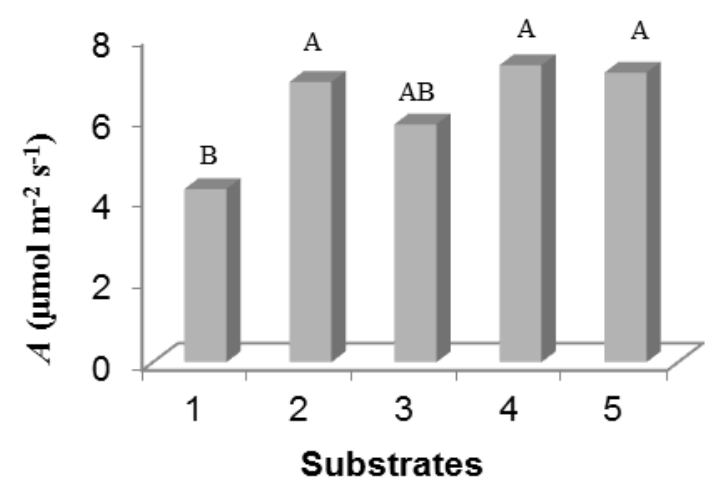

B

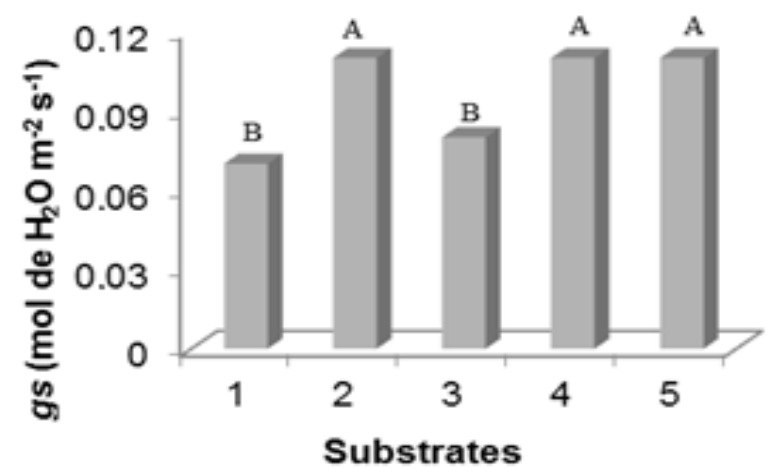

D

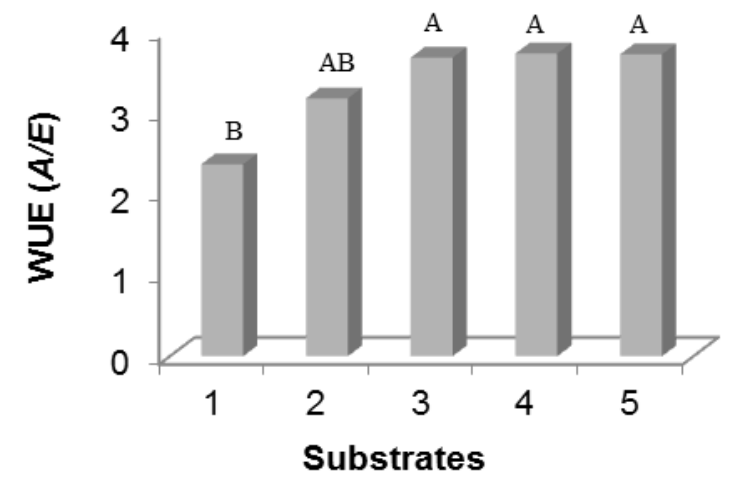

Figure 3 - (A) Transpiration (E), (B) stomatal conductance (gs), (C) CO2 assimilation rate (A) and (D) water use efficiency (WUE) of varieties of papaya in relation to substrates with different organic materials. Equal capital letters on the columns means that the averages do not differ by Tukey test $(p<0.05)$.

Note: $\mathrm{S} 1=3$ parts of soil (Neossolo Fúlvico) and 1 of washed sand (testemunha- without organic matter); S2 = 2 parts of soil, 1 of washed sand and 1 of cattle manure; S3 = 2 parts of soil, 1 of washed sand and 1 sheep manure; $S 4=2$ parts of soil, 1 of washed sand and 1 of chicken manure; $S 5=2$ parts of soil, $1 / 2$ of sand, $1 / 2$ of cattle manure, $1 / 2$ of sheep manure and $1 / 2$ of chicken manure.

Similarly to the results of stomatal conductance and intercellular $\mathrm{CO}_{2}$ concentration, the lowest net assimilation rate was observed for plants grown in the substrate ' 1 ' (control) $\left(4.26 \mu \mathrm{mol} \mathrm{m}^{-2} \mathrm{~s}^{-1}\right)$, this value being lower by $38.1,27.1,41.6$ and $40.1 \%$ in relation to the net assimilation rates of $\mathrm{CO}_{2}$ obtained in the seedlings grown in the substrates ' 2 ' (2 soil: 1 sand: 1 cattle manure), ' 3 ' ( 2 soil: 1 sand: 1 sheep manure), ' 4 ' ( 2 soil: 1 sand: 1 chicken manure) and ' 5 ' ( 2 soil: $1 / 2$ sand: $1 / 2$ cattle manure: $1 / 2$ sheep manure: $1 / 2$ chicken manure), respectively (Figure $3 \mathrm{C}$ ).

For Machado et al. (2005), virtually the entire dry matter accumulated in a plant, during its growth, comes from the photosynthetic process of atmospheric carbon fixation, which represents, on average, $95 \%$ of all the dry matter accumulated by the plant. Thus, substrates which provide higher photosynthetic rate values also favor greater growth and dry matter accumulation of seedlings. This situation can be confirmed by the relationship between the variables, since the addition of organic materials favored, to the plants, increased $\mathrm{CO}_{2}$ assimilation rate (Figure $3 \mathrm{C}$ ) and dry matter accumulation of the papaya tree seedlings (Table 4).

It is observed that the substrates ' 3 ' (2 soil: 1 sand: 1 sheep manure), ' 4 ' ( 2 soil: 1 sand: 1 chicken manure) and ' 5 ' ( 2 soil: $1 / 2$ sand: $1 / 2$ cattle manure: $1 / 2$ sheep manure: $1 / 2$ chicken manure) boosted the water use efficiency (Figure 3D), representing optimization between water loss through transpiration and assimilation of $\mathrm{CO}_{2}$ of the papaya tree seedlings (Taiz \& Zeiger, 2013). This fact is very important for the propagation of plants in hot and dry regions, typical of the northeastern Brazil, which consists of regions with semiarid climate, where the water availability and the quality of water resources are restricted (Medeiros, 2003; Holanda et al., 2010).

In the varieties of papaya tree, it was observed differentiated physiological response for the intrinsic efficiency of carboxylation depending on the substrates (Table 8). The highest values were determined in the plants of the cultivar Sunrise Solo when grown in the substrates ' 4 ' (2 soil: 1 sand: 1 chicken manure) and ' 5 ' ( 2 soil: $1 / 2$ sand: $1 / 2$ cattle manure: $1 / 2$ sheep manure: $1 / 2$ chicken manure), as can be seen in Table 8 . In the plants of the cultivar Tainung-01, the best substrates regarding the efficiency of carboxylation were '2' (2 soil: 1 sand: 1 cattle manure) and '4' ( 2 soil: 1 sand: 1 chicken manure). In the interposition between cultivars, there is disagreement to the carbon use efficiency when grown under the substrate ' 5 ' (2 soil: $1 / 2$ sand: $1 / 2$ cattle 
manure: $1 / 2$ sheep manure: $1 / 2$ chicken manure), which favored the cultivar Sunrise Solo with respect to the carbon use efficiency. The organic matter is a $\mathrm{N}$ source, which participates in the proteins involved in photosynthesis, such as the RUBISCO. This fact may have contributed to the increase in photosynthesis. Moreover, the organic fertilizer favors the availability of other nutrients that have direct effects on photosynthesis, as is the case of phosphorus and potassium.

Table 8 - Comparison test of mean (Tukey) on the variable instantaneous efficiency of carboxylation ( $\Phi$ c, $\mathrm{A} / \mathrm{C})$, between the papaya cultivars in each substrate and between substrates in each varieties of papaya.

\begin{tabular}{ccc}
\hline & \multicolumn{2}{c}{ Instantaneous efficiency of carboxylation $(\Phi \mathrm{C}, \mathrm{A} / \mathrm{C})$} \\
\cline { 2 - 3 } Substrates $(\mathrm{S})$ & \multicolumn{2}{c}{ Cultivars } \\
\cline { 2 - 3 } & Sunrise Solo & Tainung-01 \\
\hline 1 & $0.013 \mathrm{Ca}$ & $0.014 \mathrm{Ba}$ \\
2 & $0.025 \mathrm{ABCa}$ & $0.031 \mathrm{Aa}$ \\
4 & $0.019 \mathrm{BCa}$ & $0.026 \mathrm{ABa}$ \\
5 & $0.033 \mathrm{ABa}$ & $0.032 \mathrm{Aa}$ \\
& $0.037 \mathrm{Aa}$ & $0.021 \mathrm{ABb}$ \\
\hline
\end{tabular}

$\mathrm{S} 1$ = 3 parts of soil (Neossolo Fúlvico) and 1 of washed sand (testemunha- without organic matter); $\mathrm{S} 2=2$ parts of soil, 1 of washed sand and 1 of cattle manure; S3 = 2 parts of soil, 1 of washed sand and 1 sheep manure; S4 = 2 parts of soil, 1 of washed sand and 1 of chicken manure; $S 5=2$ parts of soil, $1 / 2$ of sand, $1 / 2$ of cattle manure, $1 / 2$ of sheep manure and $1 / 2$ of chicken manure; Capital letters describe the effects of substrate within each cultivar and lowercase letters, the difference between cultivars in the given substrate.

\section{Conclusions}

The use of organic fertilizer in the composition of substrates for the production of papaya tree seedlings, regardless of the source, promotes growth, dry matter accumulation and satisfactory gas exchanges to the seedlings.

The best seedlings were obtained in the substrate with 2 parts of soil, 1 part of sand and 1 part of sheep manure.

The cultivar Tainung-01 produced seedlings of better quality.

\section{References}

Araújo AC, Araújo AC, Dantas MKL, Pereira WE, Aloufa MAI (2013) Utilização de substratos orgânicos na produção de mudas de mamoeiro Formosa. Revista Brasileira de Agroecologia 8(1):210-216.

Brito MEB, Soares LAA, Fernandes PD, Lima GS, Sá FVS, Melo AS (2012) Comportamento fisiológico de combinações copa/porta-enxerto de citros sob estresse hídrico. Revista Brasileira de Ciências Agrárias 7:857-865. doi: 10.5039/agraria.v7isa1941.

Cavalcante LF, Cordeiro JC, Nascimento JAM, Cavalcante IHL, Dias TJ (2010) Fontes e níveis da salinidade da água na formação de mudas de mamoeiro cv. Sunrise Solo. Semina: Ciências Agrárias 31:1281-1290.

Costa E, Ferreira AFA, Silva PNL, Nardelli EMV (2012) Diferentes composições de substratos e ambientes protegidos na formação de mudas de péfranco de tamarindeiro. Revista Brasileira de Fruticultura 34(4):1189-1198. doi: 10.1590/S010029452012000400028.
Dickson A, Leaf AL, Hosner JF (1960) Quality appraisal of white spruce and white pine seedling stock in nurseries.Forestry Chronicle 36(1):10-13.

Embrapa - Empresa Brasileira de Pesquisa Agropecuária (1997) Manual de métodos de análises de solo. 2. ed. Rio de Janeiro: Ministério da Agricultura e do Abastecimento. 212p.

Ferreira DF (2011) Sisvar: a computer statistical analysis system. Ciência e Agrotecnologia 35(6): 10391042. doi: 10.1590/S1413-70542011000600001.

Holanda JS, Amorim JRA, Ferreira Neto M, Holanda AC (2010) Qualidade da água para irrigação. In: Gheyi HR, Dias NS, Lacerda CF (eds.), Manejo da salinidade na agricultura: estudos básicos e aplicados, FortalezaCE: INCTSal, Parte - II, Cap. 4, p. 43-61.

IBGE - Instituto Brasileiro De Geografia e Estatística. (2014) Produção agrícola municipal. <http://www.sidra.ibge.gov.br> Acesso em 23 jun. 2014.

Leitão TEMFS, Tavares JC, Rodrigues GSO, Guimarães AA, Demartelaere ACF (2009) Avaliação de mudas de mamão submetidas á diferentes níveis de adubação nitrogenada. Revista Caatinga 22(3):160-165.

Machado EC, Schmidt PT, Medina CL, Ribeiro RV (2005) Respostas da fotossíntese de três espécies de citros a fatores ambientais. Pesquisa Agropecuária Brasileira 40 (12):1161-1170.

Manica I (2006) Cultivares e melhoramentos. In: Manica I, Martins DS, Ventura JA (Eds.). Mamão: Tecnologia de Produção Pós-Colheita, Exportação, Mercados, Porto Alegre - RS: Cinco continentes, Cap. 3, p. 49-82. 
Medeiros JF, Lisboa RA, Oliveira M, Silva Júnior MJ, Alves LP (2003) Caracterização das águas subterrâneas usadas para irrigação na área produtora de melão da Chapada do Apodi. Revista Brasileira Engenharia Agrícola e Ambiental 7:469-472. doi: 10.1590/S1415-43662003000300010.

Melo AS, Costa CX, Brito MEB, Viégas PRA, Silva Júnior CD (2007) Produção de mudas de mamoeiro em diferentes substratos e doses de fósforo. Revista Brasileira Ciências Agrárias 2(4):257-261.

Mendonça AVR, Carneiro JGA, Freitas TAS, Barroso DG (2010) Características fisiológicas de mudas de Eucalyptus spp. submetidas a estresse salino. Ciência Florestal 20(2):255-267.

Mesquita EF, Chaves LHG, Freitas BV, Silva GA, Sousa MVR, Andrade R (2012) Produção de mudas de mamoeiro em função de substratos contendo esterco bovino e volumes de recipientes. Revista Brasileira de Ciências Agrárias 7(1):58-65. doi: 10.5039/agraria.v7i1a1448.

Paiva EP, Sá FVS, Mesquita EF, Barbosa MA, Souto LS, Sousa FM, Cavalcante LF, Bertino AMP (2015) Growth and efficiency of water use of papaya cultivars (Carica papaya L.) under doses of bovine biofertilizer in hydroponics cultivation. African Journal of Agricultural Research 10(22):2315-2321. doi: 10.5897/AJAR2015.9775.
Reis FO, Campostrini E (2011) Microaspersão de água sobre a copa: um estudo relacionado às trocas gasosas e à eficiência fotoquímica em plantas de mamoeiro. Revista Brasileira de Agrociência 17 (14):66-77.

Sá FVS, Araujo JL, Oliveira FS, Silva LA, Moreira RCL, Silva Neto NA (2015) Influence of silicon in papaya plant growth. Científica 43(1):77-83.

Sá FVS, Brito MEB, Melo AS, Antônio Neto $P$, Fernandes PD, Ferreira IB (2013) Produção de mudas de mamoeiro irrigadas com água salina. Revista Brasileira Engenharia Agrícola Ambiental 17(10):1047-1054. doi: 10.1590/S141543662013001000004 .

Silva LA, Brito MEB, Sá FVS, Moreira RCL, Soares Filho WS, Fernandes PD (2014) Mecanismos fisiológicos em híbridos de citros sob estresse salino em cultivo hidropônico. Revista Brasileira de Engenharia Agrícola e Ambiental 18(Suplementar):01-07.

Taiz L, Zeiger E (2013) Fisiologia vegetal. 5.ed. Porto Alegre: Artmed. 918p.

Teixeira GA, Souza HA, Mendonça V, Ramos JD, Chalfun NNJ, Ferreira EA, Melo PC (2009) Produção de mudas de mamoeiro 'Formosa' em substratos com doses de lithothamnium. Revista da FZVA 16(2):220-229. 